\title{
IMPLEMENTASI KEDISIPLINAN DAN SASARAN KERJA PEGAWAI DALAM MENINGKATKAN KINERJA DI BALAI BAHASA RIAU
}

\author{
Zihamussholihin 1) \\ Rr. Sri Kartikowati ${ }^{2)}$ \\ Fadly Azhar ${ }^{3)}$ \\ ${ }^{1)}$ Balai Bahasa Provinsi Riau, Kemendikbud \\ 2) Lecturer of Education Management Study Programme PPs University of Riau \\ ${ }^{3)}$ Lecturer of Education Management Study Programme PPs University of Riau \\ E-mail: zihamussholihinsag@yahoo.co.id
}

\begin{abstract}
This study aims to describe the implementation of discipline and performance targets of civil servant personnel of Balai Bahasa Riau. The scopes of the discipline implementation in this study deal with attendance, official dress, and work. The implementation of targets covers planning, realizing and achieving the targets. In addition, the improvement of performance of the personnel is assessed based on the implementation of the personnel discipline and the achievement of the targets in terms of both quality and quantity. Data of this study are collected through observation, faceto-face interviews with informants consisting of the head and several personnel of Balai Bahasa Riau, and analysis of documents of Balai Bahasa Riau. The method used to analyze the data is the qualitative descriptive. The data obtained are described in the form of factual explanations which begins with the data collection procession, data reduction, data presentation (data display) and ends with conclusion draw. The research findings reveal that the personnel attendance is $100 \%$ and the percentage falls in the good category. However, the number of the personnel who do not come on time is high between 12 to 16 people $(31.58 \%, 36.84 \%)$ of 38 personnel. The implementation of the personnel targets in terms of work quantity is good or in accordance with the work plan. Unfortunately, the quality of the work is not maximal yet and it needs improvement. The discipline and personnel performance targets (SKP) achievement of Balai Bahasa Riau of 2018 showed a significant improvement. The performance improvement is triggered due to the use of fingerprint attendance and electronic personnel performance targets (e-SKP) application system that bring an impact on sanctions and performance allowance cuts to those who break the rules and regulation.
\end{abstract}

Keywords: Discipline, Performance Targets, Civil Servant Personnel 


\begin{abstract}
ABSTRAK
Penelitian ini bertujuan untuk mendeskripsikan implementasi kedisiplinan dan sasaran kerja pegawai dalam meningkatkan kinerja di Balai Bahasa Riau. Lingkup implementasi kedisiplinan dalam penelitian ini adalah disiplin waktu, disiplin berpakaian dinas, dan disiplin kerja. Implementasi sasaran kerja pegawai membahas tentang menyusun rencana sasaran kerja, merealisasikan sasaran kerja, dan capaian atau target sasaran kerja. Sedangkan peningkatan kinerja pegawai didasarkan pada implementasi kedisiplinan pegawai dan sasaran kerja pegawai secara kualitas dan kuantitas pekerjaan. Teknik pengumpulan data dilakukan dengan observasi/pengamatan, wawancara langsung dengan informan yaitu kepala dan beberapa pegawai, dan studi arsip-arsip serta dokumen pada Balai Bahasa Riau. Analisis data yang digunakan dalam penelitian ini adalah metode analisis data deskriptif kualitatif, yaitu analisis data yang mendeskripsikan data yang diperoleh, kemudian dijabarkan dalam bentuk penjelasan yang sebenarnya, yang diawali dengan proses pengumpulan/seleksi data (colection), penyederhanaan data (data reduction), penyajian data (data display) dan penarikan simpulan (conclution drawing). Hasil yang diperoleh berdasarkan data dalam penelitian ini adalah bahwa tingkat absensi pegawai tergolong baik $100 \%$ hadir, hanya pada tingkat kedisiplinan kehadiran tidak tepat waktu masih cukup tinggi antara 12 sampai 16 orang (31.58\% s.d. 36.84\%) dari 38 pegawai. Implementasi sasaran kerja pegawai Balai Bahasa Riau secara kuantitas pekerjaan sudah baik sesuai dengan yang direncanakan, tetapi secara kualitas pekerjaan yang dihasilkan masih standar atau belum maksimal. Kinerja pegawai melalui implementasi kedisipilinan dan sasaran kerja pegawai (SKP) di Balai Bahasa Riau pada tahun 2018 menunjukkan peningkatan secara signifikan. Peningkatan kinerja pegawai dipicu dalam bentuk penggunaan fingerprint dan sistem aplikasi e-SKP yang berdampak pada pemberian sanksi dan pemotongan tunjangan kinerja berdasarkan peraturan perundang-undangan.
\end{abstract}

Kata Kunci: Kedisiplinan; Sasaran Kerja Pegawai; Kinerja

\section{PENDAHULUAN}

Sumber daya manusia merupakan faktor sentral dalam suatu organisasi. Apapun bentuk serta tujuannya, organisasi dibuat berdasarkan pada berbagai visi untuk kepentingan manusia, dan dalam pelaksanaan misinya dikelola dan diurus oleh manusia. Jadi, manusia merupakan faktor strategis dalam semua kegiatan institusi/organisasi.

Pegawai negeri sebagai unsur aparatur negara dan abdi masyarakat mempunyai peran sangat penting dalam pembangunan untuk menciptakan masyarakat yang taat hukum, berperadaban moderen, demokratis, tertib, bermoral tinggi dalam menyelenggarakan pelayanan secara adil dan merata kepada masyarakat. Pegawai negeri juga harus menjaga persatuan dan kesatuan bangsa dengan penuh kesetiaan kepada Pancasila dan Undang-undang Dasar 1945.

Kedisiplinan Pegawai Negeri

Sipil (PNS) merupakan suatu kewajiban yang harus dijalankan oleh setiap pegawai instansi pemerintah. Dalam tatanan legal pelaksanaannya telah diterbitkan dua penetapan aturan yaitu Peraturan Pemerintah Nomor 53 Tahun 2010 tentang Disiplin Pegawai Negeri Sipil dan Peraturan 
Kepala Badan Kepegawaian Negara Nomor 21 Tahun 2010 tentang Ketentuan Pelaksanaan Peraturan Pemerintah Nomor 53 Tahun 2010 tentang Disiplin Pegawai Negeri Sipil.

Dalam praktiknya Implementasi kedisiplinan pegawai, perlu dilakukan penanganan secara jelas sebagai cerminan prestasi kerja seorang pegawai. Begitu penting kedisiplinan pegawai negeri sipil, sehingga pemerintah melalui penetapan beberapa peraturan berupaya agar pegawai selalu melaksanakankan kedisiplinan yang juga merupakan upaya peningkatan prestasi kerjanya.

Peningkatan prestasi kerja juga dapat dilihat dari seberapa besar sasaran kerja pegawai direalisasikan. Implementasi sasaran kerja pegawai tersebut terdapat pada Peraturan Pemerintah Nomor 46 Tahun 2011 tentang Penilaian Prestasi Kerja Pegawai Negeri Sipil yang ketentuan pelaksanaanya diatur dalam Peraturan Kepala Badan Kepegawaian Nomor 1 Tahun 2013. Selain itu, Kementerian Pendidikan dan Kebudayaan melalui Biro Kepegawaian Sekretariat Jenderal memfasilitasi dengan mengembangkan sistem aplikasi elektronik Sasaran Kerja Pegawai (e-SKP) untuk digunakan pegawai dalam merencanakan dan merealisasikan sasaran kerjanya. Hal ini sebenarnya untuk memudahkan dan memacu pegawai dalam meningkatkan kinerja pegawai.

Balai Bahasa Riau merupakan instansi vertikal unit pelaksana teknis dari Badan Pengembangan dan Pembinaan Bahasa, Kementerian Pendidikan dan Kebudayaan. Sesuai dengan tugas dan fungsinya, Balai Bahasa Riau diberi tanggung jawab untuk melaksanakan berbagai kegiatan yang terkait dengan pengembangan, pembinaan, pemasyarakatan, dan pelindungan bahasa dan sastra Indonesia di Provinsi Riau. Tugas dan fungsi Balai Bahasa Riau dijabarkan dalam Peraturan Menteri Pendidikan dan
Kebudayaan Republik Indonesia Nomor 21 Tahun 2012 tanggal 19 April 2012.

Pegawai pada Balai dan Kantor Bahasa di 34 provinsi termasuk Riau bergerak di bidang bahasa dan sastra Indonesia dan daerah, yang mempunyai tanggung jawab besar akan pengembangan dan pembinaan bahasa dan sastra Indonesia di daerah. Oleh sebab itu, pegawainya diharapkan mempunyai kedisiplinan dan prestasi kerja yang baik, apalagi Balai Bahasa merupakan instansi di bawah Kementerian Pendidikan dan Kebudayaan yang sudah seharusnya menjadi contoh budaya kerja dan kedisiplinannya serta tauladan dalam pendidikan.

Dalam rangka meningkatkan kinerja pegawai Balai Bahasa Riau, implementasi kedisiplinan dan sasaran kerja merupakan faktor yang berpengaruh. Para pegawai dalam melaksanakan tugasnya tidak terlepas dari aturan kedisiplinan dan apa yang akan dikerjakan (sasaran kerja), baik yang berasal dari ketentuan internal maupun dari eksternal organisasi. Kedisiplinan dan sasaran kerja pegawai tersebut, implementasinya mengacu pada peraturan pemerintah yang berlaku sebagai tolak ukur prestasi kinerja pegawai. Kedisiplinan dan sasaran kerja harus dimiliki oleh seorang pegawai, yang tidak bisa lepas dari baik-buruknya kinerja, sebab apabila seorang pegawai kurang memperhatikan kedisiplinan dan sasaran kerjanya, maka kinerja yang diharapkan tidak akan tercapai secara optimal. Oleh sebab itu, implementasi kedisiplinan dan sasaran kerja merupakan hal mutlak yang perlu dilaksanakan untuk meningkatkan kinerja pegawai itu sendiri. Sebagaimana diungkapkan oleh Saydam (2005), pada hakikatnya, 
tujuan pemberian kedisiplinan kepada para pegawai adalah meningkatkan gairah kerja, meningkatkan disiplin kerja, meningkatkan prestasi kerja/kinerja, meningkatkan moral kerja, meningkatkan rasa tanggung jawab, meningkatkan produktivitas dan efisiensi, serta menumbuhkan loyalitas.

Disisi lain, data di lapangan menunjukkan hal yang berbeda. Berdasarkan data daftar hadir pegawai dan pengamatan atau survei yang peneliti lakukan di Balai Bahasa Riau pada bulan Februari sampai dengan Mei 2018, ditemui beberapa gejala umum dan fakta-fakta masalah perilaku kedisiplinan pegawai dengan aturan yang telah ditetapkan pemerintah. Perilaku tersebut yaitu tentang disiplin waktu (jam kerja), disiplin berpakaian (taat peraturan), dan disiplin kerja (tanggung jawab). Data kepegawaian Balai Bahasa Riau mencatat ada indikasi ketidakdisiplinan waktu yaitu keterlambatan jam kerja pegawai pada bulan Januari berjumlah 14 pegawai, Februari berjumlah 10 pegawai, Maret berjumlah 15 pegawai, April berjumlah 16 pegawai, dan Mei 2018 berjumlah 15 orang dari 38 pegawai.

Beberapa

$$
\text { gejala }
$$

prilaku

ketidakdisiplinan tersebut akan berakibat pada tertundanya aktivitas pegawai dalam mengerjakan tugas, sehingga pekerjaan pegawai terabaikan dan berdampak pada menurunnya kinerja serta terkendalanya tugas, fungsi, dan tujuan organisasi/instansi. Hal ini sejalan dengan hasil penelitian tentang Hubungan Disiplin dengan Kinerja Guru SMA Negeri di Tiga Kecamatan Kota Depok yang dilakukan oleh Sarah Wulan menemukan bahwa terdapat hubungan positif antara disiplin dengan kinerja. Berarti bahwa makin tinggi tingkat disiplin, maka makin baik pula kinerjanya. Sebaliknya makin rendah tingkat disiplin, maka makin buruk pula kinerjanya, dan disiplin yang tinggi merupakan aspek penting untuk meningkatkan kinerja (Jurnal Ilmiah Widya: 2013). Oleh karena itu peneliti ingin melihat, mengamati, dan berusaha untuk mencari dan mengetahui apakah pelaksanaan kedisiplinan dan sasaran kerja pegawai yang penerapannya mengacu pada Peraturan Pemerintah Nomor 53 Tahun 2010, Peraturan Pemerintah Nomor 46 Tahun 2011, Peraturan Kemendikbud RI Nomor 14 Tahun 2016, dan peraturan lain yang berkaitan dapat meningkatkan kinerja pegawai di Balai Bahasa Riau. Sehubungan dengan hal tersebut, maka perlu dilakukan penelitian tentang implementasi kedisiplinan dan implementasi sasaran kerja pegawai dalam meningkatkan kinerja di Balai Bahasa Riau.

\section{METODOLOGI PENELITIAN}

Penelitian ini adalah penelitian deskriptif-kualitatif dengan pendekatan model implementasi yuridis. Penggunaan metode deskriptif ini bermaksud untuk mengungkapkan data atau informasi penelitian sebanyak mungkin yang diperoleh dari lapangan, kemudian dianalisis secara kualitatif dengan pendekatan model implementasi yuridis atau penerapan terhadap peraturan-peraturan sebagai tolak ukur pelaksanaan tentang keadaan kedisiplinan dan sasaran kerja dalam rangka meningkatkan kinerja pegawai di Balai Bahasa Riau.

Penelitian dilaksanakan pada bulan Januari sampai dengan Oktober 2018 di Balai Bahasa Riau, yaitu salah satu instansi pemerintah vertikal (Kementerian Pendidikan dan Kebudayaan) yang beralamat di Jalan Binawidya, Kompleks Universitas Riau Panam, Kelurahan Simpangbaru, Kecamatan Tampan, Kota Pekanbaru, Provinsi Riau.

Penelitian ini menggunakan informan sebagai sumber data. Penentuan informan dipilih secara sengaja (purposive), Oleh karena itu, Key Informan (Informan Kunci) pada 
penelitian ini adalah kepala balai dan beberapa staf pegawai Balai Bahasa Riau.

Jenis data yang digunakan yakni

1) Data primer, yaitu (a) data hasil wawancara dengan kepala dan beberapa staf pegawai di Balai Bahasa Riau, (b) data dokumentasi penelitian, berupa foto pelaksanaan penelitian.

2) Data sekunder, yaitu dokumen print out kehadiran elektronik, dokumen SKP elektronik, dokumen kegiatan di luar kantor, dokumen kepegawaian, profil kantor, buku-buku ilmiah dan peraturan perundang-undangan yang relevan dengan penelitian ini.

Peneliti bertindak sebagai instrumen utama dengan maksud agar dapat menyesuaikan diri dengan situasi yang berubah-ubah dari informan yang diamati dan diwawancarai. Peneliti berpedoman pada wawancara yang dirumuskan dalam bentuk pertanyaan-pertanyaan. Teknik pengumpulan data mengunakan dengan studi dokumentasi, pengamatan/observasi participant, wawancara secara mendalam, dan gabungan ketiganya atau trianggulasi. Analisis data yang digunakan adalah analisis data deskriptif kualitatif dengan pendekatan model implementasi yaitu menganalisis data yang diperoleh secara kualitatif, kemudian dijabarkan dalam bentuk penjelasan implementasi yang sebenarnya, yang diawali dengan proses pengumpulan data, penyederhanaan data (data reduction), penyajian data (data display) dan penarikan simpulan (conclution drawing).

\section{Teori yang Relevan}

Implementasi bermuara pada aktivitas, aksi, tindakan atau adanya mekanisme suatu sistem. Implementasi bukan sekedar aktivitas tapi suatu kegiatan yang terencana dan untuk mencapai tujuan kegiatan (Nurdin Usman, 2002: 70). Pandangan implementasi menurut Solichin Abdul Wahab (1997:63) adalah tindakantindakan yang dilakukan baik oleh individuindividu, pejabat-pejabat, atau kelompok- kelompok pemerintah atau swasta yang diarahkan pada tercapainya tujuantujuan yang telah digariskan dalam keputusan kebijakan. Menurut peneliti Implementasi berarti pelaksanaan, penerapan kebijakan atau peraturan untuk tujuan.

Kedisiplinan adalah kesadaran atau kesediaan seseorang mentaati semua peraturan organisasi atau perusahaan dan norma-norma sosial yang berlaku. Disiplin dapat diartikan jika: (a) Pegawai selalu datang dan pulang tepat pada waktunya (b) Mengerjakan semua pekerjaan dengan baik (c) Mematuhi semua peraturan perusahaan dan norma sosial yang berlaku. Disiplin merupakan fungsi operatif manajemen sumber daya manusia yang terpenting, karena semakin baik disiplin karyawan, semakin tinggi prestasi kerja yang dicapainya. Ukuran yang dipakai dalam menilai kedisiplinan pegawai dapat terlihat dari ketepatan waktu kerja, etika berpakaian, serta penggunaan fasilitas/sarana perusahaan secara efektif dan efisien (Ibnu Syamsi, 2007:60).

Pelaksanaan kedisiplinan di Balai Bahasa Riau berdasarkan pada Peraturan Pemerintah Nomor 53 Tahun 2010 tentang Disiplin Pegawai Negeri Sipil dan Keputusan Kepala Balai Bahasa Riau Nomor 209/G5.03/KP/2011 tentang Pelaksanaan dan Penegakan Disiplin Jam Kerja dan Palkaian Kerja di Balai Bahasa Riau. Permendikbud Nomor 14 Tahun 2016, dan Surat Edaran Sekretaris Jenderal Kementerian Pendidikan dan Kebudayaan Nomor 1051/A.A6/SE/2016 tentang Pakaian Kerja Pegawai.

Sasaran Kerja Pegawai (SKP) adalah rencana kerja dan target yang dicapai oleh seorang pegawai negeri sipil (Biro Kepegawaian 
Kemendikbud, 2016). Pelaksanaan sasaran kerja pegawai berkaitan erat dengan pelaksanaan pemberian tunjangan kinerja yang ketentuannya diatur dalam Peraturan Menteri Pendidikan dan Kebudayaan Republik Indonesia Nomor 14 Tahun 2016 tantang Ketentuan Teknis Pelaksanaan Pemberian Tunjangan Kinerja Pegawai di Lingkungan Kementerian Pendidikan dan Kebudayaan (Biro Hukum dan Organisasi Kementerian Pendidikan dan Kebudayaan: 2015). Peraturan lainya yang berkaitan dengan pelaksanaan Sasaran Kerja Pegawai adalah Surat Edaran Sekretaris Jenderal Kementerian Pendidikan dan Kebudayaan Nomor 74180/A3/KP/2016 tentang Penggunaan Aplikasi Elektronik Sasaran Kerja Pegawai (e-SKP).

Kinerja yang diterjemahkan dari kosa-kata bahasa Inggris Performance, juga berarti prestasi kerja, pelaksanaan kerja, pencapaian kerja, hasil kerja, unjuk kerja, atau penampilan kerja (Amins Achmad, 2009:41). Bahwa untuk mengukur kinerja seseorang dapat terlihat pada situasi dan kondisi kerja sehari-hari, dan kinerja tersebut merupakan sebagian dari kemampuan kerja sesungguhnya yang dimiliki oleh seorang pegawai (James dkk, 1984:328). Pendapatlain menyatakan, bahwa kinerja adalah apa yang dilakukan dan tidak dilakukan oleh karyawan. Kinerja karyawan tersebut pada umumnya untuk kebanyakan pekerjaan meliputi elemen sebagai berikut: a. Kuantitas dari hasil, b. Kualitas dari hasil, c. Ketetapan waktu dari hasil, d. Kehadiran, e. Kemampuan bekerja sama (Mathisjackson, 2009:378). Menurut Henri Simamora (2012:612) faktor-faktor yang dapat dipergunakan dalam pengukuran produktivitas kerja/kinerja yaitu kuantitas kerja,kualitas kerja dan ketepatan waktu (Quality Output, Quantity Output, dan Timelinness).

\section{HASIL PENELITIAN DAN}

PEMBAHASAN

\section{Implementasi Kedisiplinan Pegawai di Balai Bahasa Riau}

\section{Disiplin Waktu}

Implementasi kedisiplinan di Balai Bahasa Riau berpedoman pada Peraturan Pemerintah Nomor 53 Tahun 2010 tentang Disiplin Pegawai Negeri Sipil. Pada pasal 3, angka 11 menjelaskan bahwa salah satu kewajiban PNS adalah masuk kerja dan mentaati ketentuan jam kerja, dan Peraturan Menteri Pendidikan dan Kebudayaan Republik Indonesia Nomor 14 Tahun 2016 yang penjelasanya diuraikan pada bagian komponen kehadiran pasal 12 sampai dengan pasal 32 .

Sarana yang digunakan dalam mengimplementasikan kedisiplinan waktu di Balai Bahasa Riau yaitu dengan menggunakan fringerprint atau alat perekam kehadiran elektronik. Setiap pegawai Balai Bahasa Riau yang hadir dan pulang mengisi daftar hadir elektonik dengan menscan sidik jari atau koreo mata pegawai melalui alat perekam (fingerprint) yang sudah diintegrasikan ke bagian kepegawaian Badan Pengembangan dan Pembinaan Bahasa, Kementerian Pendidikan dan Kebudayaan selaku instansi pusat yang mengontrol kehadiran pegawai UPT di daerah. Berdasarkan dokumen daftar hadir elektronik pegawai pada Balai Bahasa Riau sejak Januari s.d. Oktober 2018 intensitas kehadiran baik, akan tetapi terdapat beberapa pegawai yang terlambat hadir. Berikut rekapitulasi kehadiran pegawai sesuai dengan rekaman fingerprint.

Tabel Rekap Daftar Hadir Pegawai Balai Bahasa Riau Januari s.d. Oktober 2018 


\begin{tabular}{|c|l|c|c|c|c|c|c|}
\hline \multirow{2}{*}{ NO } & \multirow{2}{*}{ BULAN } & \multicolumn{5}{|c|}{ KEHADIRAN PEGAWAI BALAI BAHASA RIAU } \\
\cline { 3 - 8 } & & \multicolumn{2}{|c|}{$\begin{array}{c}\text { TEPAT } \\
\text { WAKTU }\end{array}$} & \multicolumn{2}{|c|}{ TERLAMBAT } & ABSEN & JUMLAH \\
\hline 1 & Januari & 24 & $63.16 \%$ & 14 & $35.84 \%$ & 0 & 38 \\
\hline 2 & Februari & 28 & $73.68 \%$ & 10 & $26.32 \%$ & 0 & 38 \\
\hline 3 & Maret & 23 & $60.53 \%$ & 15 & $39.47 \%$ & 0 & 38 \\
\hline 4 & April & 22 & $57.89 \%$ & 16 & $42.11 \%$ & 0 & 38 \\
\hline 5 & Meil & 23 & $60.53 \%$ & 15 & $39.47 \%$ & 0 & 38 \\
\hline 6 & Juni & 23 & $60.53 \%$ & 15 & $39.47 \%$ & 0 & 38 \\
\hline 7 & Juli & 22 & $57.89 \%$ & 16 & $42.11 \%$ & 0 & 38 \\
\hline 8 & Agustus & 26 & $68.42 \%$ & 12 & $31.58 \%$ & 0 & 38 \\
\hline 9 & September & 25 & $65.79 \%$ & 13 & $34.21 \%$ & 0 & 38 \\
\hline 10 & Oktober & 22 & $57.89 \%$ & 16 & $42.11 \%$ & 0 & 38 \\
\hline
\end{tabular}

Sumber Data Kepegawaian Balai Bahasa Riau

Daftar hadir pegawai Balai Bahasa Riau selama 10 bulan tingkat kehadiranya tergolong baik $100 \%$ hadir tidak ada yang absen, hanya saja tingkat kedisiplinan kehadiran tidak tepat waktu masih cukup tinggi antara 12 sampai 16 orang $(31.58 \%$ s.d. $36.84 \%$ )

dari 38 pegawai. Berdasarkan wawancara dengan beberapa pegawai yang terlambat hadir, mereka mempunyai alasan yang berbeda. Pelanggaran mereka masih dalam batas toleransi, karena mereka masih dapat mengganti waktu keterlambatan di waktu pulangnya. Hal ini dapat dibolehkan/dilakukan sesuai dengan Peraturan Pemerintah RI Nomor 46 Tahun 2011. Akan tetapi jika pegawai terlambatnya lebih dari pukul 08.00 s.d. 09.00, maka tidak ada toleransi penggantian waktu pada saat jam pulang, artinya pegawai dianggap terlambat terhitung dari 07.30 dan konsekuensinya ada pemotongan tunjangan kinerjanya. Jika terlambat lebih dari pukul 09.00, maka pegawai dianggap tidak hadir/absen.

Melihat dari data dokumen daftar hadir pegawai/fingerprint dan hasil wawancara beberapa pegawai, pelaksanaan kedisiplinan waktu kehadiran pegawai di Balai Bahasa Riau cukup efektif dan termonitor dengan baik, sebab telah menggunakan sistem aplikasi kehadiran elektronik yang sudah terintegrasi ke Kantor pusat. Perhitungan waktu keterlambatan juga sudah terakumulasi dengan sistem presentase pemotongan tunjangan kinrja dalam tiap bulanya. Pada kenyataannya mengenai pelaksanaan kedisiplinan waktu, pegawai Balai Bahasa Riau tidak ada yang absen tanpa keterangan dan berjalan sesuai dengan aturan, artinya setiap pegawai sudah mengetahui aturan dan sanksi serta konsekuensinya terhadap aturan yang dilanggar.

Pengamatan di lapangan, peneliti juga dapat melihat bahwa tingkat pelanggaran terhadap ketentuan jam kerja relatif kecil. akan tetapi kedisiplinan keberadaan pegawai di kantor antara waktu hadir dan pulang belum dapat terkontrol dan terindentifikasi. Hal ini perlu adanya pengawasan melekat (tim pengawas, buku kendali dan alat monitor/CCTV).

\section{Disiplin Berpakaian}

Berpakaian dinas dalam

bekerja merupakan bagian dari implementasi kedisiplinan pegawai di Balai Bahasa Riau yang berdasar pada Peraturan Pemerintah Nomor 53 Tahun 2010 pasal 3 angka 17 menyatakan bahwa setiap pegawai wajib mentaati peraturan kedinasan yang ditetapkan oleh pejabat yang berwenang. Aturan kedisiplinan berpakaian kedinasan Balai Bahasa Riau berpedoman pada ketetapan pejabat yang berwenang (eselon I) yaitu surat Kepala Badan Pengembangan dan Pembinaan Bahasa Nomor 0608/G/TU/2016 tanggal 28 Januari 2016 tentang Pakaian Kerja Pegawai dan merujuk pada Surat Edaran Sekretaris Jenderal Kementerian Pendidikan dan Kebudayaan Nomor 1051/A.A6/SE/2016 tentang Pakaian Kerja Pegawai Balai Bahasa Riau, Kementerian Pendidikan dan Kebudayaan.

Pelaksanaan disiplin berpakaian kerja di Balai Bahasa Riau 
menurut pengamatan peneliti sudah berjalan sesuai dengan aturan yang berlaku, hanya pada hari Selasa pegawai masih ada yang kurang memperhatikan untuk berpakaian pada minggu I dan III yaitu berpakaian Melayu, masih keliru dengan Minggu II dan IV berpakaian bebas rapi.

Berdasarkan wawancara dengan beberapa pegawai pada umumnya kedisiplinan berpakaian di Balai Bahasa Riau sudah dilaksanakan sesuai aturan. Pegawai telah menyadari bahwa berpakaian dinas kerja merupakan bagian ketaatan terhadap peraturan yang telah ditetapkan, apabila ada pegawai yang tidak memakai seragam hanya faktor kekeliruan dan ketidaksengajaan. Implikasi kedisiplinan pegawai berpakaian kerja merupakan bentuk dari ketaatan terhadap peraturan, sebagai identitas pegawai instansi/lembaga pemerintah, kerapian dan ketertiban, kebersamaan dan keseragaman, serta menjaga lingkungan kerja yang kondusif.

\section{Disiplin Kerja}

Hal-hal yang dijumpai peneliti di lapangan adalah bahwa disiplin kerja pegawai di Balai Bahasa Riau masih relatif rendah. Terdapat beberapa faktor penyebab rendahnya disiplin kerja pegawai, antara lain kurangnya penghargaan yang diperoleh pegawai, kurangnya dorongan atau kedisiplinan/pengawasan dari atasan, kurangnya pendidikan dan pelatihan yang diperoleh pegawai, dan kurangnya sarana dan prasarana yang menunjang.

Berdasarkan pengamatan dan wawancara yang dilakukan peneliti di lapangan, ditemukan bahwa para pegawai telah melakukan tugasnya sesuai standar yang telah ditetapkan. Namun, menurut Kepala Balai Bahasa Riau, apa yang mereka lakukan hanya berada pada batas minimum standar yang telah ditetapkan, sehingga menurut penilaian kepala bahwa kerja pegawai belum maksimal. Berarti untuk mengefektifkan pelaksanaan disiplin kerja pegawai perlu adanya agenda kerja harian, mingguan, bulanan, dan tahunan bagi masing-masing pegawai.

\section{Implementasi Sasaran Kerja Pegawai di Balai Bahasa Riau}

\section{Rencana Sasaran Kerja}

Pegawai Balai Bahasa Riau dalam menyusun rencana sasaran kerja harus sesuai dengan uraian kerja jabatan pegawai berdasarkan SK peta jabatan yang telah ditetapkan. Rencana sasaran kerja yang disusun masingmasing pegawai merupakan bagian dari perjanjian kerja/kontrak kerja pegawai terhadap kinerjanya yang akan dilaksanakan dalam satu tahun. Rencana sasaran kerja pegawai juga disusun berdasarkan kerja bulanan. Mekanisme pengisian rencana sasaran kerja pegawai Balai Bahasa Riau dilakukan secara online dengan menggunakan aplikasi e-SKP Kementerian Pendidikan dan Kebudayaan yang implikasi pelaksanaannya mengacu pada Peraturan Pemerintah Republik Indonesia Nomor 46 Tahun 2011, pada Bab II pasal 5 s.d. 9 menjelaskan tentang sasaran kerja pegawai (SKP) .

Pegawai Balai Bahasa Riau secara keseluruhan telah menyusun rencana sasaran kerja 2018 yang sudah disepakati dan disetujui oleh atasan langsung/pimpinan, hal ini peneliti lihat dari dokumen SKP dan data aplikasi e-SKP. Berdasarkan dari dokumen SKP, tidak semua unsur uraian jabatan setiap pegawai dijadikan sebagai rencana sasaran kerja, sebab alasannya berkaitan dengan waktu, kemampuan, dan kondisi volume pekerjaan yang dihadapi dan yang akan dilaksanakan.

Berdasarkan wawancara dengan beberapa pegawai Balai bahasa Riau, mereka secara keseluruhan sudah menyusun rencana 
sasaran kerja dalam format SKP elektronik dengan sistem online pada awal tahun 2018. Peneliti melihat rencana sasaran kerja pegawai melalui dokumen SKP yang sudah ditandatangani/disetujui oleh pimpinan, terlihat tidak semua unsur-unsur pekerjaan yang terdapat dalam uraian jabatan pegawai dijadikan sebagai item rencana sasaran kerja pegawai, masih dalam batas target standar, artinya belum ada yang berani mengambil diatas standar, hal ini disebabkan menghindari resiko sanksi terhadap ketidakcapaian target yang telah direncanakan. jika semua rencana kerja yang disusun tidak terealisasikan, maka juga berdampak pada besar kecilnya pembayaran tunjangan kinerja, sebab dalam Permendikbud RI Nomor 14 Tahun 2016 tentang ketentuan teknis pemberian tunjangan kinerja pegawai pada pasal 2 angka 1 disebutkan bahwa tunjangan kinerja dibayarkan berdasarkan capaian kinerja pegawai yang telah direncanakan.

\section{Realisasi Sasaran Kerja}

Berpatokan pada Permendikbud RI

Nomor 14 Tahun 2016 bahwa merealisasikan sasaran kerja pegawai dilaksanakan setiap hari dan melaporkannya melalui log harian e-SKP. Untuk itu bagi pegawai yang tidak melaporkan realiasasi sasaran kerjanya akan mendapat sanksi dan pertimbangan penilaian kinerja dari pimpinan sesuai dengan undang-undang. Berdasarkan informasi melalui hasil wawancara beberapa pegawai dan Kepala Balai Bahasa Riau, bahwa realisasi SKP harian sebagian besar sudah dilaksanakan dan dilaporkan melalui log harian e-SKP oleh pegawai Balai Bahasa Riau, hanya ada beberapa pegawai yang masih belum mengimput laporan ke log harian. Bagi pegawai yang tidak melaporkan realisasi SKP harian oleh Kepala Balai telah diberi tindakan sesuai dengan peraturan. Artinya bahwa realisasi sasaran kerja pegawai Balai Bahasa Riau dalam setiap harinya telah dilaksanakan cukup baik, tetapi belum maksimal karena masih ada beberapa pegawai yang masih harus diingatkan dalam membuat laporan log harian di e-SKP

Pernyataan hasil wawancara pada dasarnya pegawai patuh dan bertanggungjawab pada pekerjaanya dengan tidak melanggar ketentuan peraturan yang berkaitan dengan realisasi sasaran kerja yaitu Peraturan Pemerintah Republik Indonesia Nomor 4 Tahun 2011 tentang Penilaian Prestasi Kerja Pegawai Negeri Sipil tepatnya pada pasal 8 menyatakan bahwa penilaian realisasi SKP dilakukan dengan cara membandingkan antara realisasi kerja dengan target. Dan pada pasal 9 disebutkan jika SKP tidak tercapai yang diakibatkan oleh faktor diluar kemampuan individu pegawai, maka penilaian didasarkan pada pertimbangan kondisi penyebabnya.

\section{Capaian Sasaran Kerja}

Peraturan Menteri Pendidikan dan Kebudayaan Republik Indonesia Nomor: 14 Tahun 2016 tentang Ketentuan Teknis Pelaksanaan Pemberian Tunjangan Kinerja Pegawai pada Bab I, pasal 1 angka 9 menjelaskan bahwa capaian sasaran kerja adalah realisasi beban kerja setiap bulan yang dihitung secara profesional dari target sasaran kerja pegawai tahunan yang telah ditetapkan sebagai kontrak kerja. Pada pasal 2 angka 3 menjelaskan bahwa capaian sasaran kerja merupakan bagian dari komponen capaian kinerja setiap bulan berkontribusi untuk perhitungan tunjangan kinerja pegawai sebesar $60 \%$.

Berdasarkan hasil wawancara menunjukkan bahwa capaian sasaran kerja pegawai secara kuantitas sudah dapat dilakukan oleh pegawai sesuai target yang direncanakan, akan tetapi 
secara kualitas masih harus diperhatikan dan ditingkatkan. Berdasarkan berkas/dokumen penelitian yang dilakukan pegawai Balai Bahasa Riau masih banyak koreksi dan masih dalam bentuk laporan, artinya belum dapat dipublikasikan, secara output sudah dapat memenuhi hasil capaian kerja akan tetapi secara outcame belum dapat dinikmati oleh publik.

Berkaitan dengan hasil wawancara dapat disimpulkan bahwa komulatif bobot nilai capaian sasaran kerja pegawai Balai Bahasa Riau dapat mencapai diatas standar (lebih dari 76), artinya masing-masing pegawai sudah mencapai nilai 100 dengan nilai komulatif rata-rata $85-86$ perbulanya. Rekap rata-rata nilai sasaran kerja pegawai perbulan (SKP bulan Oktober 2018) menunjukkan bahwa capaian sasaran kerja pegawai Balai Bahasa Riau diatas standar yang ditentukan. Artinya bahwa capaian sasaran kerja pegawai yang direncanakan dapat terealisasikan dengan baik dan dapat dilaksanakan sesuai dengan Peraturan Menteri Pendidikan dan Kebudayaan Republik Indonesia Nomor: 14 Tahun 2016 dan Peraturan Pemerintah Nomor 2011 yang megatur tentang penilaian prestasi kinerja pegawai.

Setiap Pegawai Balai Bahasa Riau wajib melaporkan capaian sasaran kerja sesuai dengan jabatan pegawai melalui eSKP. Peraturan Pemerintah Nomor 46 Tahun 2011 tentang Penilaian Prestasi Kerja Pegawai Negeri Sipil pada c. bagian 1. menjelaskan bahwa setiap pelaksanaan kegiatan tugas jabatan harus diwujudkan secara jelas sebagai prestasi ukuran kerja, salah satu aspek bentuk output (target) adalah berupa dokumen, konsep, naskah, surat keputusan, paket, laporan, dan lainlain.

\section{Peningkatan Kinerja melalui Implementasi Kedisiplinan dan Implementasi Sasaran Kerja Pegawai di Balai Bahasa Riau}

Kedisiplinan pegawai sebagai penyelenggara pemerintahan, tentunya sangat mempengaruhi kualitas kinerja suatu pemerintahan, bahkan kedisiplinan ini bisa dikatakan sebagai salah satu indikator penting dalam mengukur keberhasilan penyelenggaraan kinerja pemerintah. Kepala Balai Bahasa Riau mengungkapkan bahwa upaya untuk meningkatkan kinerja melalui implementasi kedisiplinan dilakukan dalam bentuk pelaksanaan Peraturan Pemerintah Nomor 53 Tahun 2010 dan peraturan lainya yang berkaitan, seperti adanya (1) perekaman daftar hadir dengan fingerprint (2) pemberian sanksi pemberian penghargaan/reward, dan pengawasan.

Berdasarkan hasil wawancara dan dokumen daftar hadir pegawai tahun 2018, ada peningkatan dibandingkan dengan kehadiran pegawai berdasarkan dokumen kehadiran pegawai pada tahun 2010 sebelum diberlakukannya Peraturan Pemerintah Nomor 53 Tahun 2010. Berikut tabel perbandingan rekap daftar hadir 2010 dengan 2018.

Perbandingan Rekap Daftar Hadir Pegawai Balai Bahasa Riau 2010 dan 2018

\begin{tabular}{|c|l|c|c|c|c|}
\hline \multirow{2}{*}{ NO } & \multirow{2}{*}{ BULAN } & \multicolumn{2}{|c|}{2010} & \multicolumn{2}{c|}{2018} \\
\cline { 3 - 6 } & & Kehadiran & $\begin{array}{c}\text { Absen Tanpa } \\
\text { Keterangan }\end{array}$ & Kehadiran & $\begin{array}{c}\text { Absen Tanpa } \\
\text { Keterangan }\end{array}$ \\
\hline 1 & Januari & 29 & 9 & 38 & 0 \\
\hline 2 & Februari & 33 & 5 & 38 & 0 \\
\hline 3 & Maret & 27 & 11 & 38 & 0 \\
\hline 4 & April & 38 & 0 & 38 & 0 \\
\hline 5 & Meil & 37 & 9 & 38 & 0 \\
\hline 6 & Juni & 30 & 8 & 38 & 0 \\
\hline 7 & Juli & 33 & 5 & 38 & 0 \\
\hline 8 & Agustus & 32 & 6 & 38 & 0 \\
\hline 9 & September & 29 & 9 & 38 & 0 \\
\hline 10 & Oktober & 30 & 8 & 38 & 0 \\
\hline 11 & November & 32 & 6 & 38 & 0 \\
\hline 12 & Desember & 38 & 0 & 38 & 0 \\
\hline$\cdot$ & JuMLLAH & & 76 & & 0 \\
\hline
\end{tabular}

Tabel perbandingan rekap daftar hadir Pegawai Balai Bahasa Riau pada tahun 2010 dengan sistem manual (tanda tangan daftar hadir pegawai), dan tahun 2018 dengan 
sistem elektronik (menggunakan fingerprint) menunjukkan peningkatan kehadiran pegawai yang sangat signifikan. Ketidakhadiran tanpa keterangan pegawai Balai Bahasa Riau pada tahun 2010 tedapat hampir setiap bulan selain bulan April dan Desember. Pada tahun 2018 kedisiplinan pegawai Balai Bahasa Riau dapat ditegakkan melalui implementasi Peraturan Pemerintah RI Nomor 53 Tahun 2010 dan peraturan lainnya sebagai salah satu indikasi peningkatan kinerja pegawai di Balai Bahasa Riau.

Peningkatan kinerja melalui implementasi kedisiplinan juga dalam bentuk pemberian dorongan atau motivasi berupa sanksi dan penghargaan oleh pimpinan pada pegawai berdasarkan peraturan perundang-undangan. Pemberian sanksi terhadap pegawai yang melanggar peraturan merupakan bagian dari pelaksanaan kedisiplinan dalam upaya peningkatan kinerja pegawai.Bentuk sanksi ketidakdisiplinan pegawai sebagaimana dijelaskan oleh kepala Balai Bahasa Riau adalah berupa potongan tunjangan kinerja sebesar $40 \%$ dari presentase ketidakdisiplinan kehadiran pegawai, pemotongan tunjangan kinerja ini mekanismenya sudah diatur melalui Permendikbud Nomor 14 Tahun 2016 dan pemotongannya sudah tersistem melalui aplikasi fingerprint.

Memperhatikan efek dari sanksi pemotongan tunjangan kinerja pegawai melalui sistem daftar hadir, dapat meningkatkan kinerja pegawai di Balai Bahasa Riau pada tahun 2018 dengan tingkat ketidakhadiran tanpa keterangan pegawai 0 , jika dibandingkan dengan kinerja pegawai sebelumnya pada tahun 2010 melalui daftar hadir dengan sistem manual dan tidak ada sanksi pemotongan tunjangan dengan jumlah tingkat ketidakhadiran tanpa keterangan pegawai 85 absen. Ini berarti peningkatan kinerja pegawai melalui implementasi kedisiplinan di Balai Bahasa Riau dapat berjalan dengan efektif sesuai dengan peraturan perundang-undangan yang berlaku.

Upaya untuk meningkatkan kinerja melalui implementasi sasaran kerja pegawai di Balai Bahasa Riau salah satunya berdasarkan pada Peraturan Pemerintah Nomor 46 Tahun 2011 tentang Penilaian Prestasi Kerja Pegawai Negeri Sipil. Kinerja pegawai di Balai Bahasa Riau tahun 2018 menurut penjelasan dari Kepala Balai Bahasa Riau dapat dikategorikan tercapai dengan baik, walaupun belum diatas standar maksimal (sangat baik), karena masih ada beberapa catatan, teguran, dan diingatkan dalam menyelesaikan tugas pekerjaannya atau kurang tepat waktu, Akan tetapi setiap pegawai Balai Bahasa Riau tetap konsisten dalam melaksanakan kerja sesuai dengan tugas jabatan pegawai yang telah ditetapkan. Sistem aplikasi sasaran kerja pegawai yang diterapkan di Balai Bahasa Riau menjadi sarana untuk meningkatkan kinerja pegawai, karena pimpinan dapat memantau pekerjaan pegawai melalui e-SKP setiap hari pada log harian, setiap bulan melalui penilaian SKP bulanan, dan setiap tahun melalui penilaian prestasi kerja/kinerja pegawai. Berbeda dengan tahun 2010 yang masih menggunakan sistem manual dengan penilaian yang dilakukan hanya pada akhir tahun yaitu menggunakan Daftar Penilaian Pelaksanaan Pekerjaan (DP-3) yang diatur dalam Peraturan Pemerintah (PP) Nomor 10 Tahun 1979 Tentang Penilaian Pelaksanaan Pekerjaan PNS.

Kepala Balai Bahasa Riau dalam wawancaranya menjelaskan bahwa penilaian sasaran kerja pegawai Balai Bahasa Riau dilakukan oleh pimpinan melalui e-SKP setiap bulan. Berdasarkan catatan dokumen kepegawaian Balai Bahasa Riau nilai rata-rata sasaran kerja pegawai dari bulan Januari sampai dengan 
Desember 2018 paling rendah adalah 85,50 dan paling tinggi adalah 86,35 dapat dikategorikan Baik. Berarti mengalami peningkatan jika dibandingkan dengan nilai rata-rata kinerja pegawai pada tahun sebelumnya

Berkaitan dengan angka dan sebutan nilai rata-rata sasaran kerja pegawai Balai Bahasa Riau tahun 2018 dapat dilihat dalam tabel berikut:

Data Nilai Rata-Rata SKP Balai Bahasa Riau 2017 dan 2018

\begin{tabular}{|c|l|c|c|c|c|}
\hline \multirow{2}{*}{ NO } & \multirow{2}{*}{ BULAN } & \multicolumn{2}{|c|}{ NILAI SKP 2017 } & \multicolumn{2}{c|}{ NILAI SKP 2018 } \\
\cline { 3 - 6 } & & ANGKA & SEBUTAN & ANGKA & SEBUTAN \\
\hline \hline 1 & Januari & 84,84 & Baik & 85,50 & Baik \\
\hline 2 & Februari & 85,35 & Baik & 85,50 & Baik \\
\hline 3 & Maret & 85.73 & Baik & 85,92 & Baik \\
\hline 4 & April & 85,33 & Baik & 85,68 & Baik \\
\hline 5 & Mei & 85.29 & Baik & 85,79 & Baik \\
\hline 6 & Juni & 85,28 & Baik & 85,77 & Baik \\
\hline 7 & Juli & 85,29 & Baik & 85,74 & Baik \\
\hline 8 & Agustus & 85,29 & Baik & 85,98 & Baik \\
\hline 9 & September & 85,36 & Baik & 86,00 & Baik \\
\hline 10 & Oktober & 85,33 & Baik & 86,17 & Baik \\
\hline 11 & November & 85,48 & Baik & 86,35 & Baik \\
\hline 12 & Desember & 85,57 & Baik & 86.65 & Baik \\
\hline \hline$*$ & Nilai Rata-Rata & 85,35 & Baik & 85,85 & Baik \\
\hline
\end{tabular}

Berdasarkan tabel diatas penilaian sasaran kerja pegawai pada Balai Bahasa Riau jika merujuk pada Peraturan Pemerintah Republik Indonesia Nomor 46 Tahun 2011 tentang Penilaian Prestasi Kerja Pegawai Negeri Sipil kriteria interpretasi skor untuk variabel kinerja pegawai pada tahun 2018 dapat dikatagorikan tergolong baik dengan nilai rata-rata dalam satu tahun adalah 85,85. Jika dibandingkan dengan nilai rata-rata sasaran kerja pegawai pada tahun sebelumnya (2017) dengan skor nilai ratarata 85,35. Berarti ada peningkatan nilai rata-rata sebesar 0,50 . Jika dibandingkan dengan nilai rata-rata kinerja pegawai (DP3) tahun 2010 adalah 81, 87, ada peningkatan 3.98. Secara kualitas pekerjaan yang dihasilkan, diketahui bahwa kinerja pegawai di Balai Bahasa Riau cukup baik, para pegawai sudah tanggap terhadap pelaksanaan sasaran kerjanya. Mereka juga telah melaksanakan tugas pokok dan fungsinya dengan baik sesuai dengan yang direncanakan. Pegawai melaksanakan tugas berdasarkan uraian jabatan yang ditetapkan.

\section{SIMPULAN DAN SARAN \\ Simpulan}

1. Implementasi kedisipinan di Balai Bahasa Riau dengan menggunakan sistem daftar hadir elektronik (fingerprint) pada tingkat kehadiranya tergolong baik tidak ada yang absen tanpa keterangan atau alpa, hanya pada kedisiplinan saat kehadiran tidak tepat waktu terekam masih cukup tinggi antara 12 sampai 16 orang $(31.58 \%$ s.d. $36.84 \%$ ) dari 38 pegawai. Pemotongan tunjangan terhadap konsekuensi keterlambatan jam kerja belum mempengaruhi secara efektif terhadap pelaksanaan disiplin waktu kerja pegawai di Balai Bahasa Riau. Pelaksanaan disiplin berpakaian kerja sudah berjalan sesuai dengan aturan yang berlaku, hanya berpakaian kerja pada hari Selasa perlu menjadi perhatian yang menyebabkan kesalahan pegawai dalam berpakaian kerja. Pelaksanaan disiplin kerja pegawai di Balai Bahasa Riau relatif rendah. Ada beberapa pegawai yang masih lalai, menunda-nunda kerja, dan lambat dalam menyelesaikan laporan pekerjaan atau tidak tepat waktu. Beberapa faktor penyebab rendahnya disiplin kerja pegawai adalah kurangnya kesadaran pegawai terhadap prilaku kerja, kurangnya dorongan, tidak adanya agenda kerja harian pegawai, pengawasan dari atasan, kurangnya pendidikan dan pelatihan yang diperoleh pegawai, dan kurangnya sarana dan prasarana untuk menunjang pekerjaan.

2. Implementasi Sasaran Kerja Pegawai yaitu menyusun rencana sasaran kerja, merealisasikan sasaran kerja, dan capaian/target sasaran kerja. Implementasi sasaran 
kerja pegawai secara kuantitas pekerjaan yang diselesaikan sudah baik sesuai dengan yang direncanakan, bahkan ada beberapa pegawai yang melebihi dari capaian targetnya. Dan berdasarkan kualitas pekerjaan yang dihasilkan juga cukup baik, para pegawai sudah tanggap terhadap pelaksanaan sasaran kerjanya. Pegawai telah melaksanakan tugas pokok dan fungsinya dengan baik sesuai yang direncanakan. Pegawai melaksanakan tugas berdasarkan uraian jabatan yang ditetapkan. Akan tetapi, dari segi waktu penyelesaian pekerjaan masih ada yang lalai dan perlu diingatkan (deadline), sehingga secara kualitas pekerjaan yang dihasilkan masih belum maksimal/memuaskan.

3. Peningkatan kinerja melalui implementasi kedisipilinan pegawai di Balai Bahasa Riau pada tahun 2018 dengan sistem daftar hadir elektronik (menggunakan fingerprint), jika dibandingkan dengan tahun 2010 dengan sistem manual (tanda tangan daftar hadir pegawai), menunjukkan peningkatan kehadiran pegawai yang sangat signifikan. Peningkatan kinerja melalui implementasi kedisiplinan juga dipicu dalam bentuk pemberian berupa sanksi/potong tunjangan dan penghargaan oleh pimpinan pada pegawai berdasarkan peraturan perundang-undangan. Peningkatan kinerja pegawai melalui implementasi sasaran kerja dengan menggunakan sistem aplikasi e-SKP. Kinerja pegawai pada 2018 nilai rata-rata paling rendah adalah 85,50 dan paling tinggi adalah 86,35 dapat dikategorikan baik. Berarti mengalami peningkatan jika dibandingkan dengan nilai rata-rata kinerja pegawai pada tahun sebelumnya (2017) dengan skor nilai rata-rata 85,35. Berarti ada peningkatan nilai rata-rata sebesar 0,50. Dan jika dibandingkan dengan nilai rata-rata kinerja pegawai (DP3) tahun 2010 adalah 81, 87, ada peningkatan 3.98 .

\section{Saran}

1. Kedisiplinan keberadaan pegawai di kantor antara waktu hadir dan pulang belum dapat terkontrol dan terindentifikasi ketidakdisiplinannya. Hal ini perlu adanya pengawasan melekat (tim pengawas dan alat pengendali) seperti pemberdayaan Satpam dan pengadaan CCTV serta buku kendali.

2. Kepala Balai hendaknya mengadakan pertemuan atau apel pagi sebelum mulai bekerja untuk memberikan arahan dan moivasi kerja, selalu mengontrol pekerjaan pegawai melalui aplikasi e-SKP di android. memberikan penghargaan, memberi kesempatan kepada para pegawai untuk mengikuti pendidikan dan pelatihan, melengkapi fasilitas yang mendukung.

3. Untuk efektivitas disiplin kerja dan peningkatan kinerja, hendaknya laporan aktivitas kerja harian pegawai/Log harian dapat dijadikan sebagai alat ukur dan dasar akumulasi presentase pemotongan tunjangan kinerja bagi pegawai, dan mekanismenya dapat diatur dalam kebijakan perundang- undangan.

\section{DAFTAR PUSTAKA}

Amins, Achmad., 2009, Manajemen Kinerja Pemerintah Daerah, Laks Bang, Yogyakarta

Bernadin, Robbins, Stephen P, 2006, Prilaku Organisasi, Management, New Jersey, Penerbit Prentice Hall Inc.

Biro Kepegawaian Kementerian Pendidikan dan Kebudayaan. 2016. Sistem Informasi Kinerja Pegawai. Biro Kepegawaian Kemdikbud 
Ibnu Syamsi (Soejono), 2007. Sistem dan Prosedur Kerja. Penerbit Bumi Aksara. Jakarta

Irham Fahmi, 2010. Manajemen Kinerja Teori dan Aplikasi. Alfabeta, Bandung

James H. Donnely, James L. Gibson \& John M. Ivancevich, 1984. Fundamentals of Management, (Texas, Business Publication)

Mathis, Robert L dan John H Jackson, 2009, Human Resource Management, terjemahan, Edisi Kesepuluh, Salemba Empat. Jakarta.

Nurdin Usman , 2002, Konteks Implementasi Berbasis Kurikulum, Grasindo,Jakarta

Peraturan Pemerintah Nomor 53 Tahun 2010, Tentang Disiplin Pegawai Negeri Sipil

Peraturan Pemerintah Nomor 46 Tahun 2011, Tentang Penilaian Prestasi Kerja Pegawai Negeri Sipil

Peraturan Menteri Pendidikan dan Kebudayaan Republik Indonesia Nomor 21 Tahun 2012 Tentang Organisasi dan Tata Kerja Balai Bahasa di Lingkungan Kementerian Pendidikan dan Kebudayaan

Peraturan Menteri Pendidikan dan Kebudayaan Republik Indonesia Nomor 8 Tahun 2015 Tentang Uraian Jabatan

Peraturan Menteri Pendidikan dan Kebudayaan Republik Indonesia Nomor 14 Tahun 2016 Tentang Ketentuan Teknis Pelaksanaan Pemberian Tunjangan
Kinerja Pegawai di Lingkungan

Kementerian Pendidikan dan

Kebudayaan. Biro Hukum dan Organisasi, Kemendikbud.

Riva'i dan Basri 2004. "Penilaian Kinerja dan Organisasi”. Gramedia Pustaka Utama. Jakarta

Sarah Wulan. 2013, Hubungan Disiplin Dengan Kinerja Guru SMA Negeri Di Tiga Kecamatan Kota Depok. Jurnal Ilmiah Widya, Volume 1, Nomor 2

Saydam ,Ghozali, 2005, Manajemen Sumber Daya Manusia Suatu Pendekatan Mikro, Penerbit Djambatan, Jakarta

Simamora, Henry, 2012, Manajemen Sumber Daya Manusia, Penerbit STIE YPKN, Jakarta

Solichin Abdul Wahab. 1997. Pengantar Analisis Kebijakan Publik. Universitas Muhammadiyah Malang Press. Malang

Sugiyono., 20016, Memahami Penelitian Kualitatif. Alfabeta, Bandung.

Surat Edaran Sekretaris Jenderal Kementerian Pendidikan dan Kebudayaan Nomor 74180/A3/Kp/2016 Tentang Penilaian Prestasi Kerja Pegawai Negeri Sipil dan Penggunaan Aplikasi Ssaran Kerja Pegawai secara Elektronik 